\title{
An online course in multicultural materials for LIS graduate students at the University of South Florida \\ By Dr. Linda B. Alexander
}

\begin{abstract}
The author discusses the content included in an online course on "Multicultural Materials for Young Adults and Children." This graduate course (LIS 5937) for Library and information Science students at the University of South Florida, is a very popular offering for those who plan to work with youth in libraries. The class teaches students how to respond to the reading needs of our diverse patron base by understanding aspects of their values and customs as well as their ways of interacting.
\end{abstract}

The American Library Association's “Diversity Action and Inclusion Plan" expresses the vision of the organization as "...a richly, diverse workforce providing a high level of service to the membership in an environment where respect, appreciation, equity, and inclusion are core values.” Since we live in a very diverse culture, it is important to spell out some of the characteristics in which we differ. The document further explains that "...in addition to race, creed, color, religion, gender, disability, and national origin, differences include: language origin, regional and geographic background, economic class, education, learning and communication styles, and sexual orientation and personal lifestyle” (ALA). Learning about varied cultures within our society can be partially accomplished by including multicultural literature in our library services and programs. Librarians must be cognizant and up-to-date on how to respond to the reading needs of people of diverse cultures. This focus of this article is on multicultural reading for youth, including teens, tweens, and children. This author developed a graduate Library and Information Science course at the University of South Florida in Tampa during 2003-2004 to educate graduate library students on how to respond to the reading needs of our diverse patron base by understanding aspects of their values and customs as well as to their ways of interacting.

Tomlinson and Lynch-Brown (2001) cite five reasons multicultural literature has value for all children:

- Children of varied cultures who see positively represented characters in multicultural literature derive self-esteem and pride in their heritage.
- Children, parents, teachers, and librarians learn about and become aware of other peoples and their cultures.

- Multi-cultural literature shows children that other groups are worthy, and that they have something to teach others.

- Emotional involvement and vicarious experience with multi-cultural characters through literature reduce students' prejudices toward the micro-culture.

- Reading about issues and problems peculiar to children of a specific micro-culture from the perspective of story characters who themselves are members of the group can help children of that micro-culture to cope with the same problems themselves (190-191).

\section{The Course}

Creating a course in multicultural materials for librarians seemed to be a mandate as a response to the diversity mission and vision expressed by ALA. During the 2003-2004 academic year, the author began work toward creating an elective online course in Multicultural Materials for Young Adults and Children for graduate students in the School of Library and Information Science at the University of South Florida. Extensive research went into determining the knowledge and skills needed by librarians for responding to diverse patrons and developing course materials. These included textbook selections, websites, journal articles, and book titles for the various cultures included. The elective course was first offered during the Fall, 2004, semester, with the target audience of graduate students and librarians working with youth in public or school libraries. Although one section of the class was originally offered, the student demand was so high the first semester that a second 
section was opened to meet this demand. Approximately 55 students took the class that fall semester, and one section or more of the course has been offered every fall and spring semester since that date. The course, LIS 5937, is always full to the limit of 30 students per section.

\section{Course Textbook}

The text selected for the course was a book from the Sage counseling series titled Increasing Multicultural Understanding: A Comprehensive Model by Don C. Locke (1998). The alternative choice was Hazel Rochman's book Against Borders: Promoting Books for a Multicultural World, published in 1993. Locke's book is more recent but does not contain any book lists for reading about the cultures. However, an element of the Locke text that influenced the choice was the way each chapter on a particular culture was arranged into ten rudimentary psychosocial topics throughout, including:

- acculturation

- poverty and economic concerns

- history of oppression

- language and the arts

- racism and prejudice

- sociopolitical factors

- child-rearing practices

- religious practices

- family structure and dynamics

- cultural values and attitudes.

As mentioned, the Locke text discusses various peoples but not their literary creations. The content is intended to help counselors better understand patients by learning about their ethnic identities and how this affects them. It teaches readers about eleven multicultural groups prevalent in the U.S., but is not without its weaknesses. It often paints a rosy picture, omits important details, and does not represent different groups in the text equally to their percentage in the population. For example, the book dedicates four out of twelve chapters to Asian Americans, which comprise less than $4 \%$ of the total U. S. population. In contrast, Hispanic Americans, who represent over $12 \%$ of the total U.S. population, were given only two chapters, and African Americans, also at $12 \%$ of the population are given only one chapter. Cuban-Americans, who are the third largest component in the Hispanic-American population, were completely overlooked. Another important group ignored by the text is the Haitian-Americans, with a U.S. population (particularly in Florida and New York) of over two million. ("United States: Population by Race"). Although the text is highly informative, these omissions are a serious concern in this context.

Since the text does not deal with literature per se, the book course lists and websites are important to students taking this course. To supplement student reading, several books are mentioned in the course as suggested reading, such as the Rochman book, Carlos Diaz's Multicultural Education for the 21st Century, James and Cherry Banks' 2005 edition of Multicultural Education: Issues and Perspectives, and Vicki L. Gregory's resource book Multicultural Resources on the Internet, a 1999 Booklist Editors' Choice.

\section{The Cultures}

Since space prohibits elucidation other than a condensed representation of the cultures covered in the course, the following section addresses each culture covered, with a few of its distinctions, according to Locke.

African Americans are a biracial community, which draws upon standardized African American behavior and the dominant culture. Economically, this community has twice the unemployment rate of the dominant culture, with fewer high-paying jobs and lower wage rates than whites. Generally speaking, religion and church attendance is a socializing institution and a source of leadership. The family structure involves strong kinship bonds, adaptability of family roles, and a strong work orientation.

The Amish community believes in complete separation from the world, and has strict rules about behavior, dress, language usage, education, and religion. They speak three distinct tongues: Pennsylvania German, High German, and English. All aspects of the Amish life are determined by their religious practicies. They do not participate in violence, and believe in adult baptism and disciplined church community, where shunning is strictly enforced. As farmers, they value harmony with soil and nature.

Native American Indians have the lowest average income, educational level, and standard of living of any group covered in the course. Their culture has a 
rich heritage in nonverbal language with over 300 tribal languages in use in contemporary communities. Politically, their tribal governments vary. While historically they used chiefs, currently most use a tribal council type of government. Their religious beliefs are holistic with many gods or spirits; they usually have one chief God or Great Spirit and worship the forces of nature and animals. Much of the familiar literature for children and teens about this group is not based on authenticity to the culture. The Oyate organization (http://www.oyate.org/) distributes materials and discusses problematic titles (http://www.oyate.org/booksto-avoid/) . Surprisingly, according to this website, some of the "worst" titles include: Little House on the Prairie by Laura Ingalls Wilder, Sitting Bull and His World by Albert Marrin, My Heart is on the Ground by Ann Rinaldi, and Wounded Knee by Neil Waldman.

Chinese Americans have no single Chinese language, but the major dialects are Cantonese and Mandarin; which use a different symbol for each word. Filial piety and veneration of age mean obedience and devotion to parents where the eldest sons have specific obligations to family. The religions they practice include Confucianism, Buddhism, and Taoism. One of the cultural pressures is that one must behave in a way that will not shame the family, because if irreconcilable problems occur, the family will disown the problem member.

Japanese Americans are the third largest Asian group (after Chinese Americans and Filipinos) in the United States. One cultural feature involves their use of body language, where they use very little eye contact, and instead of handshaking they bow. The Japanese do not admit any need of "personal space." They practice Buddhism, Confucianism, and Shintoism. The family structure is patriarchal, where the mother is devoted to child-rearing and the father is an exemplar to children and his authority is unquestioned.

A unique characteristic of the Korean American community is that they have only 232 surnames. Appproximately $53 \%$ of the population has one of five major surnames: Kim, Lee/Rhee/Yi, Park, Choi/Choe, and Chung/Jung. The typical parents are in their late 30s, with two or three children of elementary school age. Korean Americans usually have a high school or college education. Their cultural emphasis is on suppression of strong feelings, obedience to family authority, and subjugation of individuality to benefit the family.

Vietnamese Americans have been politically oppressed throughout history, living under U.S. resistance to all things Vietnamese after the Vietnam war. They lived under the traditional caste system, with scholar being at the top and merchant being at the bottom of the social class structure. Regarding the family structure, children remain with the family until marriage and, after marriage, women transfer allegiance to their husband's family.

The Hispanic/Latino community poses two central questions: "Who is Hispanic? Who is Latino?" These two terms are often used interchangeably. There are numerous and varied Latino and Hispanic cultures which differ widely from each other. Among the American communities are Cuban, Dominican, Guatemalan, Colombian, Venezuelan, and Peruvian. In Florida for example, the population is made up of less people from Mexico, but many from Cuba, Puerto Rico, the Dominican Republic, and Central America, It's important to remember that Florida was settled by the Spanish, so the Hispanic and Latino people there have a Spanish cultural heritage, but may or may not speak Spanish.

Mexican Americans are usually bilingual, but some Mexican Americans speak no Spanish and some speak no English, although the majority speak both languages. Mexican Americans grow up in a childcentered home where the parents tend to be permissive and indulgent with the younger children. The religion is predominantly Roman Catholic, and the church is the center of faith. Worship services may be informal with guitars, accordions, maracas, etc. With respect to

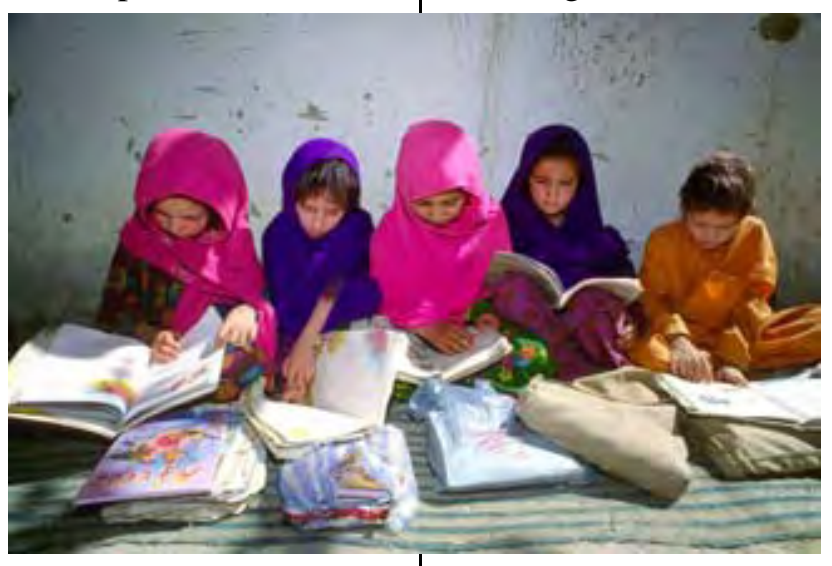
the family structure, there may be no single family pattern based on one culture.

Forty-two percent of all Puerto Ricans live in the U.S., with the highest concentration residing in New York City. This group did not experience discrimination based on race until they came to the U.S.; prejudice in Puerto Rico is based on class, not color. Those living in the U. S. have also experienced a shift in values. There has been a change in the roles of men 
and women, with women becoming more independent, and children behaving more like the dominant culture (aggressive, competitive, inquisitive, independent, selfreliant).

Jewish Identity in American is difficult to describe due to very diverse origins, yet this population has a high degree of religious and cultural identity. Jewish languages includes Hebrew, Aramaic, Yiddish, and Latino. Their history of the Holocaust, during which time six million Jews were killed, represents one-third of the world's Jewish population and $60 \%$ of European Jewry. The major focus of political activity is their commitment to Zionism and to the prosperity of Israel. American Jews have become more acculturated than some other communities, with education levels being higher and poverty less of a factor.

There is a tremendous amount of racism and prejudice in the U.S. regarding Muslim

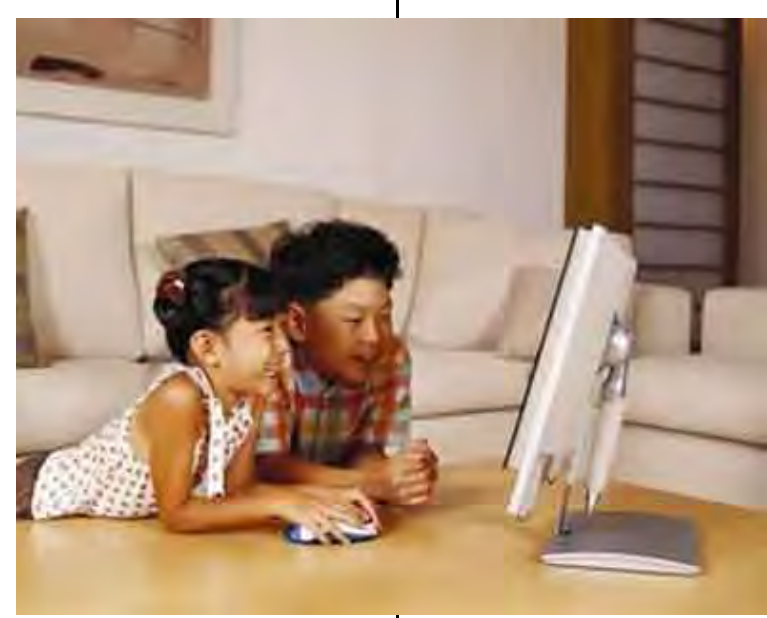
communities due to the negative image of Islam, especially after the Sept. 11, 2001, tragedy. Their religion and non-representational art are foremost characteristics, with the use of Arabic script that transcribes the Qur'an into beautiful script as act of devotion. The patriarchal family structure honors fulfilling the masculine roles and fathering children, especially sons. Public worship is at the heart of Islamic practice.

Americans with disabilities is a group that is not discussed in the Locke text, but was added to the course as an important group served by librarians. Unfortunately, this category is too large to discuss in this space. It includes, but is not limited to, persons with psychological, physical, educational, social, agerelated, and various other characteristics that identify them for services above and beyond the usual.

Another group not covered in the Locke text includes the gay community, or the Gay-Lesbian-BisexualTransgendered-Questioning (GLBTQ) group. Gay describes a man who is romantically and sexually attracted to other men, and also sometimes is an inclusive term encompassing gay men, lesbians, bisexuals, and sometimes even transgender people. A lesbian is a woman who is romantically and sexually attracted to other women, while bisexual people have the capacity to form romantic and sexual relationships with both men and women. Transgendered people have a gender identity construct that differs from their physical sex. Questioning people are in the process of evaluating their gender identity and/or sexual orientation. Queer is considered an offensive term but is sometimes used within the GLBTQ community.

Since students in the course only read books for young adults on this topic, the concepts of intellectual freedom and book challenges form a part of the study of this community.

\section{Evaluating Multicultural Materials}

Students enrolled in this course are expected to read two books per week on the culture being studied during the fourteen weeks: a young adult title and a children's title. A major component of the course is the evaluation of materials' quality of according to the criteria suggested by experts on materials for diverse cultures.

These criteria include:

- General Accuracy.

- Stereotypes. A misleading book might discuss "the Mexican experience." This is one to avoid.

- Accurate Setting. Not all Native Americans lived in teepees.

- Language. Does the book use the language of the culture? Students are taught to become aware of books that divide characters into two groups those who speak standard English and those who do not.

- Insulting epithets. If the content is insulting, err on the side of protecting children.

- Illustrations. In The Five Chinese Brothers the characters all look alike. Avoid ilustrated books with this characteristic.

- Author's perspective. An author with an insider's perspective is much preferred. This approach is controversial because many in the literary arts believe that an author must actually live in a culture to write about that culture with accuracy. Others disagree, feeling that an author can write about other cultures with a spirit of truth. This issue is particularly interesting in fiction where authors often write under the aegis of another gender and even sometimes race. 
- Appealing stories. Themes such as friendship, family, and school appeal to youth.

- Tough Issues. Does the book offer multiple perspectives on tough issues? For example, Less than Half, More than Whole by Kathleen and Michael Lacapa is a good portrayal of biracial issues.

\section{Assignments}

Since LIS 5937 is listed in the SLIS curriculum as an elective rather than a required core course, assignments for the class are fewer than the typical LIS graduate class. Students are required to read fourteen young adult books and fourteen children's books during the fourteen-week semester. Students select books, many of which are award titles, from a list of titles for each cultural group provided in the online Blackboard courseware corresponding to each chapter in Locke's text. There is no corresponding reading in the Locke book for the disability or the GLBTQ groups so students are provided a list of a variety of professional journal articles for background reading. Numerous websites are available for additional information for each culture. Students must evaluate a number of the books read, using the criteria discussed above. They also must compare and contrast in some detail the book's culture and traditional American/Western culture, stating possible program connection ideas for library settings.

Students are required to post weekly to the course discussion board thoughtful comments with regard to Locke's categories of psychosocial topics compared with the book content read by the student for the culture of each week. An online quiz is required during the course, which covers awards, organizations, and other historical library information associated with services to diverse cultures. Although the quiz is open book, it is recognized that a quiz is part of the total learning experience, even when students look up answers.

A short research paper on any library or access issue of a special population is required. This task necessitates the use of the University of San Francisco (USF) Virtual Library and its databases for procuring scholarly sources to support the arguement. The final capstone assignment is the development of an inclusion and awareness program on a culture of one's choice to be used in a stated library setting that serves a diverse patronage for teens and children. This program is presented in a face-to-face class meeting near the end of the semester. Handouts are distributed to all class members so that these programs can be adapted or duplicated in various settings by all the students at a later date. Those who are actually employed libarians usually prepare a program they will use in the future, while students who are not yet employed in a library create a hypothetical program.

\section{National Recognition}

An interesting event came about as the result of one of the student's project, which she decided to use in her part-time job in a local public library. Meagan Albright created a GLBTQ program, using her display of gaythemed books for young adults in her Hillsborough County library during the Gay Pride month of June. Three adult patrons were offended by the display being positioned near the front door of the library, although only one of them made a formal complaint in writing. This gay book display for teen reading received national attention when the Hillsborough Board of County Commissioners (BOCC) ruled in a separate statement that no gay materials could be displayed in any public building in the county. Alas, the BOCC had overstepped their boundaries. This incident became an intellectual freedom issue as a First Amednment right was being violated. The BOCC's action resulted in the Florida Library Association stating they would boycott Hillsborough County for any future meetings; a lawsuit was also filed by a private citizen within the county. Articles on the Hillsborough County ban appeared in the New York Times, American Libraries, and various local newspapers thoughout the summer. Although the kind of attention the ban received was not preferred, the attention reecived for this act by the BOCC drew attention not only to Tampa and to the School of Library and Information Science at USF, but to the course itself. It was also brought to the attention of the Intellectual Freedom Committee of the ALA.

In summary, this course has filled a gap for library students who will be working in academic, public, and school libraries in Florida and other states. The need for a course such as this is more and more evident as our nation becomes more diversified in the 21st century. Although the course is merely an introduction to other cultures, there will be a need for more intense courses like this for training our next generation of librarians-courses which include various populations not covered in LIS 5937 and at more depth than the current course can cover. All in all, LIS 5937 has proven to be a successful course for generating a 
decided contemplation and reflection on the diverse patrons we serve.

\section{References}

American Library Association. (n.d.). The diversity vision. Retrieved September 30, 2006, from http://www.ala.org/ala/diversityactionb/ALA_Diversity Action_and_Inclusion_Plan.pdf.

Gregory, Vicki L., Stauffer, M.K. , and Keene, Tom. (Eds). (1999). Multicultural resources on the Internet: The United States and Canada. Littleton, CO: Libraries Unlimited.

Locke, Don C. (1998). Increasing multicultural understanding: A comprehensive model. (2nd ed.). Thousand Oaks, CA, Sage.

Tomlinson, Carl M., \& Lynch-Brown, Carol. (2001). Essentials of children's literature $\left(4^{\text {th }}\right.$ ed.). Boston: Allyn and Bacon.

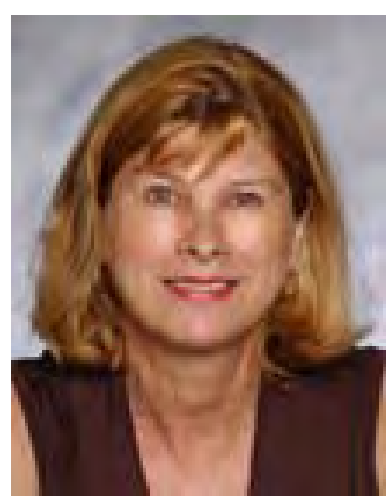

Dr. Linda Baldwin Alexander has been involved with the library profession since receiving her MLS in 1986. Since 2001, she has been teaching graduate classes in the School of Library and Information Science (SLIS) at the University of South Florida in Tampa. In 2004, she began teaching a class she developed called "Multicultural Materials for Young Adults and Children," which has been in high demand by graduate students in the SLIS every semester since.

Alexander has a master's degree in Education with a core specialty in special education, the MLS degree, and a master degree in Adult Education, all from East Carolina University. She obtained her Doctoral degree in Higher Education Administration in 2000 from the University of Louisville. Dr. Alexander's main interests lies in the education areas for youth pleasure reading and reading across the curriculum and outreach to diverse populations in our society, in meeting the needs of ADA patrons in libraries, and in access to health and government resources in the information age.

For Dr. Alexander, the various divisions of the SLA serve as a huge enhancement for her in her work towards delivering resources for librarians, information agents, and media specialists. She uses the SLA website for gaining information about corporate, academic, and government librarianship and information specialists, since many of her students do fieldwork in these areas, including newspaper offices (i.e., St. Petersburg Times).

In her free time (what is that?) she collects resources on holistic health, information about the stereotypical image of the librarian, and does a little bit of gardening. To vent her frustrations, she picks weeds in her garden, a habit that seems to be very therapeutic as a stress-reducer.

Alexander also noted that the course she designed, LIS 5937, will very soon (perhaps by the time you're reading this) become a permanent course and will then be called LIS 5566.

lalexand@cas.usf.edu

Books in Brief - By Jacqueline Snider

Book Review \& Liaison Editor

The Data guidebook for Teachers and Leaders: Tools for Continuous Improvement

Depka, E. (2006). The Data guidebook for Teachers and Leaders: Tools for Continuous Improvement. Thousand Oaks, CA: Corwin Press. 94 p. ISBN: 1-4129-1754-9 (cloth) \$56.95; 14129-1755-7 (pbk.) \$29.95.

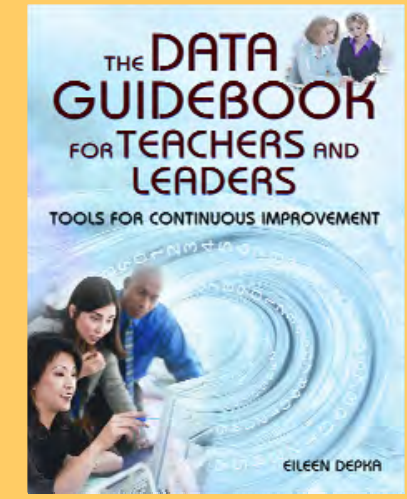

This book shows the connection between data collection and student achievement. The process is a constant and cyclical one. The book identifies the five W's: who are involved, what are collected, when are the data analyzed, where are the data collected, and why are they analyzed. The cycle revolves around analysis, planning, implementation, and assessment. The author describes standardized and state test data, and their importance in school improvement. To assist teachers, the book includes rubrics, reflections, worksheets, and strategies. 